\title{
Leadership Styles and Their Applications for Effective School Administration
}

\author{
Dr. Helen Jonathan Mshelia \& Olukayode Emmanuel (B.Sc, NMIN, M.Sc in view) \\ Department of Educational Foundations, Taraba State University Jalingo, Nigeria \\ DOI - http://doi.org/10.37502/IJSMR.2022.5204
}

\begin{abstract}
This empirical study discussed the different types of leadership styles and how they can be adopted for effective Administration of schools. Its objectives were to examine how the school administrators' leadership styles affect the performance of school resources and to develop methods in which administrators can enhance their styles towards the realization of school goals. It analyzed school as a social system, various kind of leadership styles, leadership styles application, causes of leadership style failure and suggested ways of improving school administrator's leadership styles. It is however concluded that there is no single ideal leadership style; rather, the ability to use all of them depending on the situational demand is the key to becoming a relevant and high-performing school administrator.
\end{abstract}

Keywords: leadership styles, performance of school.

\section{Introduction}

Administration is an all-round harmonization and utilization of available human, fiscal, materials, time resources in the most effective and efficient means in order to achieve personal or corporate goals and objectives. It is a series of predetermined actions geared towards ensuring adequate involvement of stakeholders in realization of common goal(s). The success or failure of an organization is determined by the strength and weakness of its administration because most organizational decisions have its implementation and execution by the kind of leadership style adopted by its manager or administrator. Furthermore, the current global upsurge towards the acquisition of quality education has created anxiety in the hearts of stakeholders in the education sector on the types of leadership styles which school administrators /principals should adopt for effective and efficient implementation of national curriculum which would pave way for high educational output (Igwe et al, 2017). Owning to this, a critical examination of leadership styles is germane for a reproductive system of a country and as such is a school.

Leadership Style could be seen as the leader's choice of ways of planning, leading, controlling, staffing and organizing resources in attainment of set goals. Every organization whether formal or informal has an administrator who stands to run the affairs of it. It could be a church, mosque, business venture, charity home, school etc. School as a formal 
organization is headed by different educational administrators at different levels for different purposes.

The basic and post basic levels are headed by a head teacher or principal, Rector for college of education, Provost for polytechnic and Vice-chancellor for University. As a result of this, Leadership style differs in dimension and could either be result-oriented (autocratic), workers-oriented (Democratic), Indifferent (Laissez-faire), transactional (Telling), transformational (Selling) etc.

The school, as an organization consists of large numbers of people whose opinions, ideas, habits and attitudes are varied and may mirror the full range of interests and conducts experience in the wider community (Robbins, 1992) thus, there is need for a dynamic administrator who is well knowledgeable to manage educational inputs towards meeting both academic, psychological, socio-economic and personal needs of stakeholders in education.

In an organization where factors of production are poorly managed, inadequate payment of worker's salary, poor working environment, lack of staff welfare packages, rigid rules and regulations; lawlessness in service delivery, staff might become disinterested and unproductive at the expense of organizational goals. So also it is in a school system, when the leadership style of a school administration is not favorable to stakeholders involved; teaching might become unenthusiastic for teachers and lawless in service delivery, students might become truants and threat to the peace of the school and its environs, parents might withdraw their children from the school, communal clashes might surface and government might shut down schools. As a result of this, a dynamic leadership style that is responsive to achieve its goals while adequately managing stakeholders effectively and efficiently is of high necessity. It is important to deal with effective leadership styles performed by the principals as these indeed play the most important role for effective schools and determining students' excellence in academic performance (Igwe et al, 2017)

\section{School as a Social System}

Talcott Parsons was the first formulator of Social systems. They are based on interpersonal relationships regardless of their size and complexity, and they consists of individual actors interacting in a culturally structured system full of shared symbols (Parsons, 1951). Social systems have three basic characteristics called the interdependence of the parts, their organization into some sort of whole, and the intrinsic presence of both individuals and institutions (Getzels, Lipham \& Campbell, 1968).

Internal and external relationship among people formed the basis of school as a social organization. The communication within the school environment, host and neighboring communities are essential tools for social cohesiveness/ socialization which have vital roles to play for its growth in building and maintaining relationships which can be considered as a process by which principals and teacher link learning that occurs inside and outside the school (Kowalski, 2010).

Problems may occur when roles and personalities conflict (Getzels, Lipham \& Cambell, 1968). So, School administrators must jealously prioritize compatibility of individual personality/characteristics with roles to avoid conflicting interests of stakeholders. 


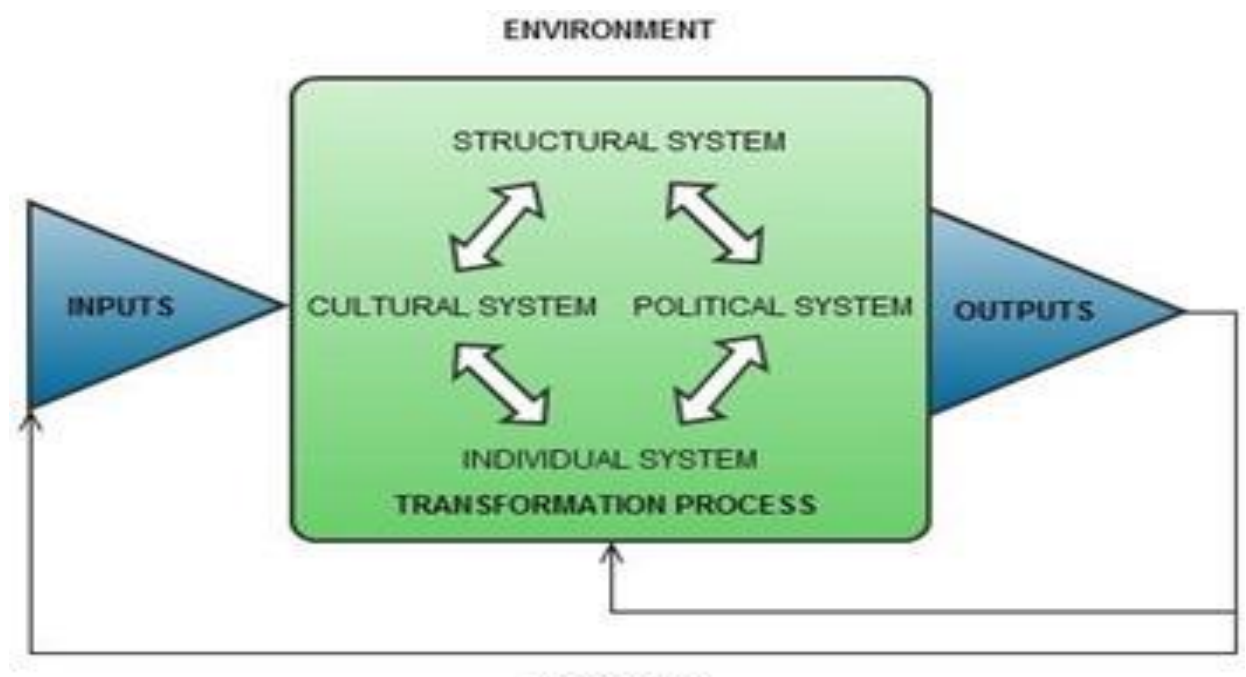

FEEDBACK

Elements of social system (Hoy \& Miskel, 2005, p. 31).

Inputs: Educational inputs are the resources expended towards achieving the national or specific goals of a school such as; school facilities, equipment, teachers, non -teaching staffs, information, infrastructural facilities, instructional materials, furniture, finance, time etc. When these are not efficiently managed, it has threatening effect on the process resulting to output of unemployed and unemployable graduates.

Environment / Community: School is a microcosm of a given community whose policy, plans and programs are dependent on the structural system, cultural system, political system and individual system of the community in transforming all educational inputs into a desirable output. When these are not efficiently managed, it weakens the bond between the school and its environs thereby resulting to communal clashes, strike, dissatisfaction, moral delinquency, work overload and in general poor educational delivery in quality.

Outputs: These are the number of pupils who successful complete the cycle of a given level of education which could be; Primary, secondary or tertiary level of education. The productivity or quality of this is determined by the feedback mechanism of the system when the recipients are able or unable to respond to the challenges of their immediate environment by the virtue of experience, knowledge and character gained through the walls of school.

\section{Leadership Styles and Their Applications}

Leadership is a function of some given personality attributes which is based on notion that an individual's behavior is partly the product of his personality (Oyedeji, 2013). An effective school leader is the one whose personality is in tandem with attributes exhibited by situational factors which is based on what the need of the time is. To critically analyze this, several authors have written exhaustively on different types of leadership styles which could be adopted for effective school administration such as; democratic, autocratic, laissez faire, transformational, transactional, committee styles of leadership etc.

In the course of this topic, the major leadership behaviors that are being identified and generally exhibited in practical life would be discussed which are; Democratic style, Autocratic style and Laissez faire, Transactional and Transformation. 
1. Democratic Leadership style: This is a Joint-decision making approach to the attainment of set goals, concern for staff and work are at the average. The school principal work towards achieving school goals while ensuring that staff welfare packages are not compromised. This kind of leadership style gives room for staff innovation and development. It is relationshiporiented.

2. Autocratic Leadership style: This is also known as an authoritarian approach to decision making. Decisions are made by the school administrator (s) alone who thinks he knows everything than anybody else. There is little or no concern for staffs as it is task oriented in nature, superlative interest in achieving work objectives and do not give room for staff opinions or participation. It is "Do as I Say" in practice. This kind of approach is more reflected in its rigid rules and regulations, work terms and conditions, importance on unquestionability to authority.

3. Laissez faire Leadership style: This is an indifferent behavior to staff welfare, work and organizational expectations. Managers have little or zero concern in attaining school objectives and stakeholders demands. Teachers are not self- motivated, low selflessness, low morale and inept attitudes to work. This kind of approach gives room for bribery and corruption, unethical behavior of teachers, moral delinquency of students, staff degradation and poor quality delivery.

4. Transactional Leadership style: This is a 'quid pro quo' (something for something) approach in practice. It is a "Telling leadership style' emphasizing positive and negative reinforcement in realization of goal. It is reactive in nature, appeals to self- interest, focus on result and depend on self- motivated people. Transactional leaders motivate followers through exchange; for example, accomplishing work in exchange for rewards or preferences (N, jundeswaraswamy et al, 2014). This leadership style gives room for mastery and competence.

5. Transformational Leadership style: This is an opposite of transactional style. It is a "Selling leadership style". It emphasizes motivation and inspiration, proactive in approach, focuses on corporate progress and motivate staffs for mastery in taking future roles. This kind of leadership style gives room for commitment, efficient production, team spirit and timely realization of school goals because it has higher concern for both staff and work. The aim of transformational leadership would be to transform people and organizations inside a literal sense (Bass, 1993)

\section{Applications for Effective School Administration}

The understanding and application of leadership style by educational administrators such as head teachers, principals, rectors, provosts, vice chancellors, ministries, boards and commissions will enable them to adequately utilize and adopt expected leadership style for holistic and productive management of their institutions.

Autocratic or authoritarian leadership style is used when leaders tell their employees what they want done and how they want it accomplished, without getting the advice of followers 
(Adeyemi, 1998). This kind of leadership style is often-time effective when driving towards change or matters that needs urgency such as impromptu visitation of external supervisors, commissioner's visit, press visitation in matters related to abduction or death of students, discipline of erring students etc. However, this style results in the group members reacting aggressively and uninterestingly to the authority in the work environment (Igwe et al, 2017). It is therefore suggested that authoritarian style should be rarely used my educational managers as this might lead to dispute and conflicting interest of parties involved of which in the long run would affect the overall achievement of goals.

The participative or democratic leadership style is the principal involving stakeholder(s) in the decision making or planning process in determining; what to do, how to do, who to do, when to do and for whom to be done? It is participatory in nature by its constant call for meeting: Staff meeting, Parents and Teachers Association (PTA) meeting, Congress meeting etc. However, the leader maintains the final decision making authority. Using this style is not a sign of weakness; rather, it is a sign of strength that your employees will respect (Obama, Eunice and Orodho, 2015).

Nsubuga (2008) maintains that an effective principal pays more attention to planning work, special tasks and permits teachers to participate in decision making in achieving school goals. Using this style is of mutual benefit making processes in an effort to allow them to become part or the team and allows you to make better decisions. According to Ogunsanwo, (2000) the participatory leadership style provides a climate of sense of unity in pursuit of set goals.

Delegative or free reign is where the leader allows the employees to make the decisions. This is used when employees are able to analyze the situation and determine what need s' to be done and how to do it.

The laissez-faire style of leadership according to Flippo and Munsinger, (1982) is where a leader succumbs to Theory Y. The theory argues that people are innately motivated, naturally like to do work and therefore there should be no rules since everybody has an inborn sense of responsibility. However, this style of leadership may result in indiscipline due to nonenforcement of rules and regulations in a school leading to poor performance in both national and external examinations. Pervasive and sustained student learning is more likely to occur in schools with strong instructional leadership. Morphet, Johns and Reller (1974) stress that administrative efficiency will be valid only to the extent to which it will contribute to the attainment of goals of the organization, the goals of actors in the organization and the extent that it will meet the requirements of the environment for that survival of the organization. Bell (1992) notes that effective leadership will provide schools with a vision, explicit philosophies laid on consultation and team work and lead to success in attainment of good results in national examinations.

\section{Causes of School Leadership Styles Failure}

The following are the causes of leadership failures of a school administrator;

Leadership Stereotypes: Male societal stereotypes include competitive, adventurous, assertive, daring, dominant, resilient, action oriented and able to stand up to pressure. The 
communal stereotypes for the females are compassionate, soft, sensitive, supporting, kind and considerate. It is not strange that there can be discrimination about who is appointed as a leader since the stereotyped leadership attributes are inherently connected with men. This kind of belief or notion is present everywhere even in schools as female administrators might be despised by male subordinates and thereby could weaken the leadership style of the said female school administrator. However, it is expected of a school administrator to be in the best position of influencing and effecting change in the school without prejudice and fear of cultural belief.

Failure to Serve: To be a successful leader, there must be a sense of servant-hood in action. Leadership at times may not only necessarily demand giving orders and supervision of works but also by serving the led. A school principal must be able to show a sense of service to his or her subordinates by helping them do basic responsibilities where and when the need be. No administrator or manager is too big to serve as this is a pill for administrative retention, attraction and relevance.

Resistance to Change: School is an open as well as a close system drawing its plans, policy and programs from different sources which to a large extent is determined by the level of interaction and negotiation between its externalities and internalities. A school administrator leadership styles would be ineffective if he or she could not adjust to changes of operation that may come from either within or outside the school. For instance, an authoritarian school administrator of a primary school can fail in leadership role if he or she is transferred to school where the teachers, students and PTA are used to a democrat style of policy making. Hence, dynamism is expected to be displayed of the school administrator if he or she would dare to achieve individual and corporate goal(s) of the school.

Head in the Sand syndrome: This simply means avoiding to tackle or respond to a particular situation by pretending not to be aware of it. This kind of leadership style is peculiar to the laissez-faire as he or she fails to recognize and take actions against ineptitude disposition of staffs, students and colleagues at the management level. A school principal should be able to shun unethical behaviors such as lateness to school, corporal punishment on students, bullying, examination malpractice, immoral acts, delayed salary payment of staffs, poor working conditions of teaching and non-teaching staffs without prejudice or preference. Administrators of educational institutions are expected to give full cognizance of all threatening needs, demands and emerging issues associated to stakeholders as the absence of this could cause unforeseeable problems.

Fear: The fear of losing one's dignity or authority in decision making and delegation of duties could make a democrat school administrator fail. Delegation is part of administrative ethics that makes a wholesome manager. A democratic school administrator could be inefficient in achieving set goals if he or she fears delegating duties to a seemingly professional subordinate (Vice-principal) who can help in supervising, monitoring and evaluating the performance of low-level teachers in the school.

Others causes include the following; lack of trust in subordinates, leaders negative attitude1s, lack of professional degrees, leading without insight etc. 


\section{Ways of improving leadership style of a school administrator}

To improve one's leadership style, the following are of importance;

A school administrator must invest in himself/herself for personal and professional development.

A school administrator must be an active listener and action taker.

He or she must be cognizance of staffs strength and weakness as well as make provisions for improvement and development.

He or she must be a leader at the front of school affairs.

He or she must adopt and practice all the leadership styles when the need arises. A school administrator must not stick to one leadership style as it may not be effective in an institution that's not structured to a one-leadership styled approach.

\section{Conclusion}

Adeyemi and Bolarinwa (2013), brought into focus a dimension of leadership style that is associated with the autocratic/ democratic continuum. This is the task orientation-versus relationship-oriented style of leadership with the task orientation being similar to the autocratic method and the relationship oriented style being similar to the democratic method. According to the authors, current research has established that the difference between the effectiveness and ineffectiveness of the leadership styles is the appropriateness of the leader's behavior to the particular situation in which it is used. In a nutshell, there is no one-size-fitsall leadership style for a high- performing school administrators or manager; rather, a combination is recommended and should be applied depending on the situation demanded.

\section{References}

1) Adeyemi, T.O (1998). School and teachers variables associated with the performance of students in the senior secondary school certificate examination in Ondo State, Nigeria Unpublished Ph.D. Thesis, University of Hull, England, United Kingdom.

2) Babalola J.B and Atanda A.I (2006). Management Thoughts and Educational Management. Ibadan; Codat publications.

3) Bass B.M and Avolio B. J., Transformational leadership and Organizational Culture, Public Administration Quarterly, 12, 113-121 (1993)

4) Filippo, E.E and Munsinger, G.M ( 1982) Management, Boston: Allyn and Bacon Inc ( publishers)

5) Getzels, J.W, Liphan,J.M and Campbell, R.F ( 1968). Educational Administration as a Social Enterprise. New York, Harper \& Row.

6) Igwe, N.N, Ndidiamaka M.O \& Chidi, A. F (2017). Principals Leadership Styles and Students' Academic Performance in Enugu metropolis: A comparative Survey of Public and Mission Secondary Schools. Archives of Business Research, 5(8), 7-30.

7) Kemp, R and Nathan, M. (1989). Middle management in Schools: A Survival Guide. London; Basil wall Ltd.

8) Kowalski,T.J (2010). The School Principal: Visionary leadership and competent management. New York, Routledge. 
9) Nan jundeswaraswamy T.S \& Swamy D.R (2014). Leadership Styles. Department of Industrial Engineering and Management, JSS Academy of Technical Education, Bangalore, India.

10) Nsubuga, Y.K (2008) Analysis of Leadership Styles and School Performance of Secondary Schools in Uganda, Thesis Nelson Mandela Metropolitan University.

11) Ogunsanwo, O.A (2000) Modern principles and Techniques of Managers. Ibadan External Studies Programmes, Department of Educational Management, University of Ibadan 2, 4-90.

12) Oyedeji, N.B (2013) Educational Anomaly and the Educational Administrator. 140th Inaugural Lecture. University of Ilorin, Ilorin Nigeria.

13) Parsons, T. (1951). The Social system. New York. Free press

14) Robbins S. (1996). Organizational Behaviour (7th edition), New York. Longman Publishing Inc. 